\title{
Mineral trioxide aggregate in primary molar pulpotomies
}

\author{
Would mineral trioxide aggregate be a good replacement for formocresol in \\ primary molar pulpotomies?
}

\begin{abstract}
Holan G, Eidelman E, Fuks AB. Long-term evaluation of pulpotomy in primary molars using mineral trioxide aggregate or formocresol. Pediatr Dent 2005; 27:129-136

Design Quasi-randomised controlled trial.

Intervention Primary molar teeth were treated using a conventional pulpotomy technique but received either mineral trioxide aggregate (MTA, test group) or formocresol (FC, control group) as a pulp dressing. Follow-up clinical (not blind) and radiographic (blind) assessments were undertaken every 6 months.
\end{abstract}

Outcome measure Time elapsed between treatment and either 1) detection of pulpotomy failure 2) natural exfoliation of tooth 3) patient's last visit for recall. Pulpotomy success rate $=$ (number of teeth in which pulpotomy did not fail)/ (total number of treated teeth) $\times 100$.

Results In total, 62 pulpotomised teeth were available for analysis, 29 in the FC group and 33 in the MTA group. Treatment failure occurred in six teeth (one treated with MTA and five with FC) after a mean of 16 months (range, 4-30 months). Pulpotomy success rates were $97 \%$ for MTA and $83 \%$ for FC. The mean follow-up time was 38 months (range, 4.-74 months), in which there was no significant difference between test and control groups.

Conclusions No statistically significant difference was found in the success rates of MTA and FC in this long-term evaluation of pulpotomy in primary molars.
Address for correspondence: Dr Holan, Senior Lecturer, Department of Paediatric Dentistry, The Hebrew University, Hadassah School of Dental Medicine, Jerusalem, Israel.Email: holan@cc.huji.ac.il.

\section{Commentary}

Recently, there has been a resurgence of research on pulp therapy and pulp medicaments for primary teeth. More and more clinicians wish to avoid the use of formocresol, traditionally used as pulp medicament after pulpotomies. This generally well conducted study, from a respected research group, addressed a clearly focused question to assess clinically and radiographically, the effects of MTA as pulp dressing material following pulpotomy in primary molars compared to Formocresol. Most of the basic principles of clinical prospective research which are desirable, but sadly lacking in many clinical studies, were followed. In addition to including teeth with pulp exposure, teeth asymptomatic teeth with deep carious lesions were also included in the study. This is a strength of the study because it is well known that teeth with deep proximal carious lesions, but no pulp exposure manifest pulp inflammation and should also be included in such studies

Teeth were allocated using coin toss then alternation, but allocation concealment was not applied. Randomisation was done at the tooth level therefore, some children may have had several teeth included with different treatments which is not considered a good practice from a statistical view point but sometimes unavoidable in clinical research where access to a large sample is difficult. After the pulp amputation, for those cases where formocresol was used as a medicament, zinc oxide eugenol (ZOE) was applied on the remaining root canal tissue. It is well known that ZOE itself has an inflammatory effect on the pulp and therefore this is a compounding factor that may affect the treatment outcome. Also, different types of final restorations with different success rates, were placed after the pulp therapy, which may confound the outcomes, though in this article all the failures were observed in the teeth restored with stainless steel crowns.

Table 1. Follow-up times and confidence intervals

\begin{tabular}{|c|c|c|c|c|c|c|}
\hline \multirow[b]{2}{*}{ Measure } & \multicolumn{2}{|c|}{ FC group } & \multicolumn{2}{|c|}{ MTA group } & \multirow[t]{2}{*}{ Difference } & \multirow[t]{2}{*}{$95 \% \mathrm{Cl}$} \\
\hline & Mean & SD & Mean & SD & & \\
\hline $\begin{array}{l}\text { Longest } \\
\text { possible } \\
\text { follow-up } \\
\text { time until } \\
\text { shedding }\end{array}$ & 34.37 & 14.50 & 31.20 & 14.30 & 3.17 & $\begin{array}{l}101.98 \\
-108.32\end{array}$ \\
\hline $\begin{array}{l}\text { Longest } \\
\text { possible } \\
\text { follow-up } \\
\text { time until last } \\
\text { examination }\end{array}$ & 53.00 & 13.02 & 48.14 & 11.68 & 4.86 & $\begin{array}{l}72.22 \\
-81.94\end{array}$ \\
\hline $\begin{array}{l}\text { Longest } \\
\text { possible } \\
\text { follow-up } \\
\text { time until } \\
\text { failure }\end{array}$ & & & 10.21 & 12.00 & 4.47 & $\begin{array}{l}20.22 \\
-29.16\end{array}$ \\
\hline
\end{tabular}

FC, Formocresol; MTA, mineral trioxide aggregate; SD, standard deviation; CI, confidence interval. 
Success (shedding) or failure rate of both interventions was determined at different follow-up periods according to defined failure criteria. An important outcome that was not assessed in this study is pain. Intention to treat analysis which aims to reduce bias was not performed to include the 2 drop outs from the FC group, but as the number of drop outs was small it should not have influenced the results.

The author's conclude that MTA showed a higher (not statistically significant) long term clinical and radiographic success rate than FC and can be recommended as a replacement for FC. We calculated the $95 \%$ CI for the difference in means (Table 1), and observed very wide intervals indicating that more data should be collected before anything definite can be said about the studied parameters. Furthermore, based on the high risk of selection bias, performance bias, confounders and the small number of subjects in this study, the evaluation of long term success rates, costs, risks of harm, and expectations of benefit of MTA compared to FC in primary molar pulpotomies cannot yet be done.

\section{Monty Duggal and Mohammed Al Ansary}

Department of Paediatric Dentistry, Leeds Dental Institute, Leeds, UK

1. Higgins JPT, Green S (Eds). Cochrane Handbook for Systematic Reviews of Interventions 4.2.5 [May 2005 update]. In the Cochrane Library, issue 3. Chichester: John Wiley; 2005.

2. Altman DG, Machin D, Bryant TN, Gardner MJ (Eds). Statistics with Confidence. 2nd Edn. London: BMJ Books; 2000.

3. Moher D, Pham B, Jones A, Cook DJ, Jadad AR, Moher M, et al. Does quality of reports of randomised trials affect estimates of intervention efficacy reported in meta-analyses? Lancet 1998; 352:609-613.

4. Moher D, Jadad AR, Tugwell P. Assessing the quality of randomized controlled trials: current issues and future directions. Int J Tech Assess Health Care 1996; 12:195-208.

5. Swinscow TDV. Statistics at Square One. 9th Edn. London: BMJ Books; 1996.

6. Chatfield C. Problem Solving. A Statistician's Guide. London: Chapman and Hall; 1995.

7. Begg CC, Cho M, Eastwood S, Horton R, Moher D, Olkin I, et al. Improving the quality of reporting on randomised controlled trials: the CONSORT statement. J Am Med Assoc 1996; 276:637-639.

Evidence-Based Dentistry (2006) 7, 35-36.

doi:10.1038/sj.ebd.6400395 